\title{
2'-O-Methyl-8-methylguanosine as a Z-Form RNA Stabilizer for Structural and Functional Study of Z-RNA
}

\author{
Thananjeyan Balasubramaniyam ${ }^{1}$, Takumi Ishizuka ${ }^{1}\left(\mathbb{D}\right.$, Chao-Da Xiao $^{1,2}$, Hong-Liang Bao $^{1}$ and \\ Yan $\mathrm{Xu}{ }^{1, *(D)}$ \\ 1 Division of Chemistry, Department of Medical Sciences, University of Miyazaki, 5200 Kihara, Kiyotake, \\ Miyazaki 889-1692, Japan; balasubramaniyam_thananjeyan@med.miyazaki-u.ac.jp (T.B.); \\ tishizuka@med.miyazaki-u.ac.jp (T.I.); choutatsu_shou@med.miyazaki-u.ac.jp (C.-D.X.); \\ xiaobujiao@163.com (H.-L.B.) \\ 2 The key Laboratory of Optimal Utilization of Natural Medicine Resources, School of Pharmaceutical \\ Sciences, Guizhou Medical University, University Town, Guian New District, Guiyang 550025, China \\ * Correspondence: xuyan@med.miyazaki-u.ac.jp; Tel.: +81-985-85-0993
}

Received: 5 September 2018; Accepted: 7 October 2018; Published: 9 October 2018

\begin{abstract}
In contrast to Z-DNA that was stabilized and well-studied for its structure by chemical approaches, the stabilization and structural study of Z-RNA remains a challenge. In this study, we developed a Z-form RNA stabilizer $\mathrm{m}^{8} \mathrm{Gm}$, and demonstrated that incorporation of $\mathrm{m}^{8} \mathrm{Gm}$ into RNA can markedly stabilize the Z-RNA at low salt conditions. Using the $\mathrm{m}^{8} \mathrm{Gm}$-contained Z-RNA, we determined the structure of Z-RNA and investigated the interaction of protein and Z-RNA.
\end{abstract}

Keywords: Z-RNA structure; synthesis of oligonucleotide; NMR; circular dichroism

\section{Introduction}

The RNA helixes mostly adopt a right-handed A-from geometry. Another RNA conformation is characteristic of left-handed RNA having alternating CG base pairs [1,2]. Z $\alpha$, a Z-form-binding domain of RNA-editing enzyme ADAR1, has been found to specifically bind to Z-DNA and Z-RNA [3-9]. It has been reported that Z-RNA participates in the interferon-response pathway $[10,11]$ or viral inhibition [10-12]. The physical, chemical and spectral data on Z-RNA have been collected, whereas the biological role of Z-RNA has long been in question due to the difficulty of obtaining stable Z-RNAs under physiological salt conditions. For example, an A- to Z-RNA transition requires a very high salt concentration, e.g., $6 \mathrm{M} \mathrm{NaClO}_{4}[1,2]$.

Several studies have been reported on incorporating modified nucleic acid residues for the stabilization of Z-DNA [13-21]. Notably modified guanine residues highly favor the formation of Z-DNA. We have previously reported that the methylation of the C8 position of guanine significantly stabilized the Z-DNA because the modification by methylation was favorable for the syn conformation of the nucleobases [17]. Based on the results of these past studies, we have now developed a Z-form RNA stabilizer that stabilizes Z-RNA under physiological salt conditions. We designed and synthesized a 2'-O-methyl-8-methyl guanosine $\left(\mathrm{m}^{8} \mathrm{Gm}\right)$ by insertion of a methyl group at the C8 position of $2^{\prime}$-O-methyl guanosine. We found that incorporation of the $\mathrm{m}^{8} \mathrm{Gm}$ in the RNA dramatically stabilized the Z-RNA, even under physiological salt concentrations, and facilitated the A- to Z-RNA transition, even for AU-containing sequences that do not favor the formation of Z-RNA. We then determined the solution structure of $\mathrm{r}\left(\mathrm{CGC}\left[\mathrm{m}^{8} \mathrm{Gm}\right] \mathrm{CG}\right)_{2}$. This allowed us to see the effect of the incorporation of a $\mathrm{m}^{8} \mathrm{Gm}$ on RNA and allowed us to understand the Z-RNA structure. The Z-RNA stabilizer can also be used to investigate the interaction of the $Z \alpha$ domain and Z-RNA. 


\section{Results and Discussion}

We synthesized the $\mathrm{m}^{8} \mathrm{Gm}$-incorporating oligonucleotides by phosphoramidite chemistry, using 2'-O-methyl guanosine (Schemes S1, S2 and Figures S1-S7). The induction of a methyl group in the C8 position highly favors the syn conformation. These structural features can lead the $\mathrm{m}^{8} \mathrm{Gm}$ to greatly stabilize Z-RNA. Using nuclear Overhauser effect (NOE) between $\mathrm{C}^{\prime} \mathrm{H}$ and $8 \mathrm{CH}_{3}$, we confirmed the syn conformation of $\mathrm{m}^{8} \mathrm{Gm}$ (Figure S8).

Circular dichroism (CD) spectroscopy has been used to study the Z-form conformation [17,22]. A-RNA, a negative Cotton effect appears around $295 \mathrm{~nm}$, whereas in Z-RNA, a more positive band appears at $280 \mathrm{~nm}[23,24]$. Thus, we performed CD spectroscopy experiments to study the conformation using various $\mathrm{NaClO}_{4}$ concentrations.

We used the CD spectroscopy to examine the A-Z transition under various salt concentrations. Native RNA r(CGCGCG) 2 in A-form does not transfer to the Z-form, even in the presence of $3 \mathrm{M} \mathrm{NaClO}_{4}$ (Figure $\left.1 \mathrm{a}\right) \cdot \mathrm{m}^{8} \mathrm{Gm}$-incorporated $\mathrm{r}\left(\mathrm{CGC}\left[\mathrm{m}^{8} \mathrm{Gm}\right] \mathrm{CG}\right)_{2}$ showed a Z-form CD spectrum with increasing concentrations of $\mathrm{NaClO}_{4}$. (Figure 1b). The midpoint $\mathrm{NaClO}_{4}$ concentration for $\mathrm{r}\left(\mathrm{CGC}\left[\mathrm{m}^{8} \mathrm{Gm}\right] \mathrm{CG}\right)_{2}$ was $880 \mathrm{mM}$, lower than that of the native RNA (4090 mM) (Table 1). $\mathrm{r}\left(\mathrm{C}\left[\mathrm{m}^{8} \mathrm{Gm}\right] \mathrm{C}\left[\mathrm{m}^{8} \mathrm{Gm}\right] \mathrm{CG}\right)_{2}$ containing two $\mathrm{m}^{8} \mathrm{Gms}$ greatly stabilized the Z-form, showing a Z-form CD spectrum even in the presence of $50 \mathrm{mM} \mathrm{NaClO}_{4}$ (Figure S9) at a lower physiological salt concentration, and the midpoint was $100 \mathrm{mM}$ (Table 1).

The incorporation of $\mathrm{m}^{8} \mathrm{Gm}$ can stabilize the Z-form containing an AU base pair. It showed the typical Z-form with $2360 \mathrm{mM}$ midpoint compared to the native RNA (Figure S9 and Table 1). Octamer RNA containing four $\mathrm{m}^{8} \mathrm{Gms}$ in double strands also effectively stabilized the Z-form with $850 \mathrm{mM}$ midpoint.

We designed a short duplex containing only one modified base, $r\left(C\left[m^{8} \mathrm{Gm}\right] C G U\left[m^{8} \mathrm{Gm}\right] C G\right) /$ $\mathrm{r}(\mathrm{CGCACG})$, in which the underlined sequences can form a duplex containing only one $\mathrm{m}^{8} \mathrm{Gm}$ base. We compared its stability with native RNA r(CGCGUGCG)/r(CGCACG). Although the 6 base pairs duplex containing an AU base pair does not favor the formation of Z-RNA, it facilitated the A- to Z-RNA transition as compared to native 6 base pairs RNA (Figure S10). The midpoint for RNA containing one $\mathrm{m}^{8} \mathrm{Gm}$ was $4000 \mathrm{mM}$, lower than that of the native RNA (>6000 mM) (Figure S10), indicating that only one $\mathrm{m}^{8} \mathrm{Gm}$ can stabilize the Z-form, indicating that only one $\mathrm{m}^{8} \mathrm{Gm}$ can stabilize the Z-form.


Figure 1. CD spectra of native RNA r(CGCGCG) $)_{2}(\mathbf{a})$ and $\mathrm{m}^{8} \mathrm{Gm}$-contained $\mathrm{r}\left(\mathrm{CGC}\left[\mathrm{m}^{8} \mathrm{Gm}\right] \mathrm{CG}\right)_{2}(\mathbf{b})$ ( $0.15 \mathrm{mM}$ base concentration) at $10^{\circ} \mathrm{C}$ with various $\mathrm{NaClO}_{4}$ concentrations in $5 \mathrm{mM}$ sodium phosphate buffer ( $\mathrm{pH} 7.0)$. 
Table 1. Midpoint $\mathrm{NaClO}_{4}$ concentration in A-Z transition.

\begin{tabular}{lc}
\hline \multicolumn{1}{c}{ Oligonucleotides } & $\mathbf{N a C l O}_{\mathbf{4}}(\mathbf{m M})$ \\
\hline $\mathrm{r}(\mathrm{CGCGCG})_{2}$ & 4090 \\
$\mathrm{r}\left(\mathrm{CGC}\left[\mathrm{m}^{8} \mathrm{Gm}\right] \mathrm{CG}\right)_{2}$ & 880 \\
$\mathrm{r}\left(\mathrm{C}\left[\mathrm{m}^{8} \mathrm{Gm}\right] \mathrm{C}\left[\mathrm{m}^{8} \mathrm{Gm}\right] \mathrm{CG}\right)_{2}$ & 100 \\
$\mathrm{r}(\mathrm{CGCGUGCG}) / \mathrm{r}(\mathrm{CGCACGCG})$ & 5430 \\
$\mathrm{r}(\mathrm{CGCGUGCG}) / \mathrm{r}\left(\mathrm{C}\left[\mathrm{m}^{8} \mathrm{Gm}\right] \mathrm{CAC}\left[\mathrm{m}^{8} \mathrm{Gm}\right] \mathrm{CG}\right)$ & 2360 \\
$\mathrm{r}\left(\mathrm{C}\left[\mathrm{m}^{8} \mathrm{Gm}\right] \mathrm{CGU}\left[\mathrm{m}^{8} \mathrm{Gm}^{\mathrm{G}}\right] \mathrm{CG}\right) / \mathrm{r}\left(\mathrm{C}\left[\mathrm{m}^{8} \mathrm{Gm}\right] \mathrm{CAC}\left[\mathrm{m}^{8} \mathrm{Gm}\right] \mathrm{CG}\right)$ & 850 \\
\hline
\end{tabular}

To further understand the $\mathrm{m}^{8} \mathrm{Gm}$ effect on the thermodynamic properties of Z-RNA, the melting temperature $\left(T_{\mathrm{m}}\right)$ and thermodynamic parameters were examined using $\mathrm{CD}$ melting experiments. $\left(T_{\mathrm{m}}\right)$ values of $\mathrm{m}^{8} \mathrm{Gm}$-incorporated hexamer RNA increased by $6-15^{\circ} \mathrm{C}\left(\Delta T_{\mathrm{m}}\right)$, (Figure 2a and Table 2$)$, and octamer RNA with four $\mathrm{m}^{8} \mathrm{Gms}$ in double strands containing an AU base pair increased even more, by $15{ }^{\circ} \mathrm{C}$ (Figure $2 \mathrm{~b}$ and Table 2). Thermodynamic parameters revealed a very favorable free energy of formation for the $\mathrm{m}^{8} \mathrm{Gm}$-incorporated Z-RNA compared to the native RNA (Table 2) suggesting that the syn conformation of $\mathrm{m}^{8} \mathrm{Gm}$ was thermodynamically favorable, and the preferred $\mathrm{C}^{\prime}$ endo conformation of ribose induced by the $2^{\prime}-O$-methyl group also contributed to the stabilization of the $Z$-form, which is consistent with the previous study $[1,25]$. The advantages of $2^{\prime}-O$-methyl substituent include provision of an NMR signal from 2'-O-methyl group for NMR structure study, easy-to-prepare phosphoramidite reagent more than $2^{\prime}$-O-hydroxy group for the chemical introduction of $\mathrm{m}^{8} \mathrm{Gm}$ into RNA oligonucleotides, and efficient resistance to enzymatic cleavage of oligonucleotide $[1,26,27]$.

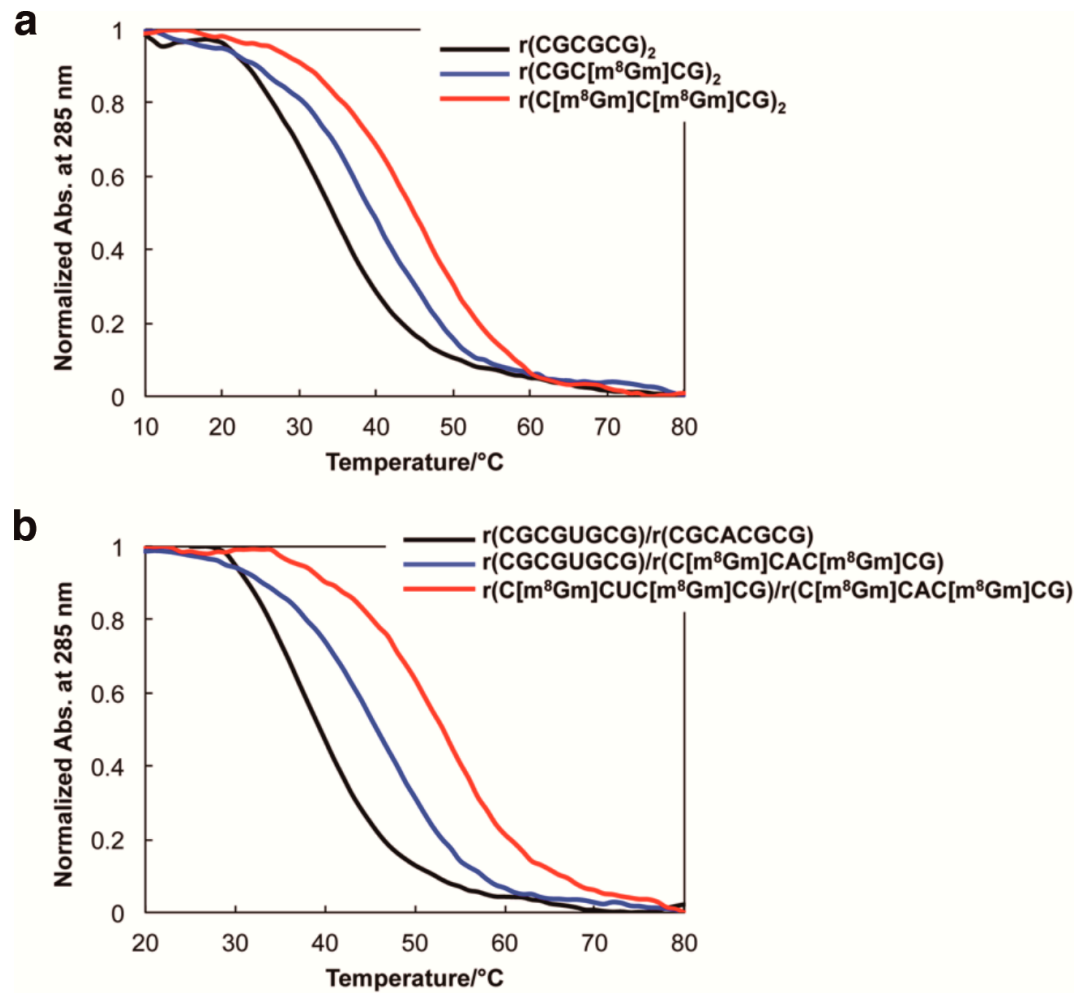

Figure 2. (a) CD melting curves for native RNA r(CGCGCG) $)_{2}$ (back line), $r\left(C G C\left[m^{8} \mathrm{Gm}\right] C G\right)_{2}$ containing one $\mathrm{m}^{8} \mathrm{Gm}$ (blue line), and $\mathrm{r}\left(\mathrm{C}\left[\mathrm{m}^{8} \mathrm{Gm}\right] \mathrm{C}\left[\mathrm{m}^{8} \mathrm{Gm}\right] \mathrm{CG}\right)_{2}$ containing two $\mathrm{m}^{8} \mathrm{Gms}$ (red line). (b) CD melting curves for RNA sequences containing an AU base pair, native RNA r(CGCGUGCG)/ $\mathrm{r}(\mathrm{CGCACGCG})$ (back line), $\mathrm{r}(\mathrm{CGCGUGCG}) / \mathrm{r}\left(\mathrm{C}\left[\mathrm{m}^{8} \mathrm{Gm}\right] \mathrm{CAC}\left[\mathrm{m}^{8} \mathrm{Gm}\right] \mathrm{CG}\right)$ having two $\mathrm{m}^{8} \mathrm{Gms}$ in one strand (blue line), $r\left(\mathrm{C}\left[\mathrm{m}^{8} \mathrm{Gm}\right] \mathrm{CGU}\left[\mathrm{m}^{8} \mathrm{Gm}\right] \mathrm{CG}\right) \mathrm{r}\left(\mathrm{C}\left[\mathrm{m}^{8} \mathrm{Gm}\right] \mathrm{CAC}\left[\mathrm{m}^{8} \mathrm{Gm}\right] \mathrm{CG}\right)$ having four $\mathrm{m}^{8} \mathrm{Gms}$ in two strands (red line). In $5 \mathrm{mM}$ sodium phosphate buffer ( $\mathrm{pH} 7.0), 7 \mathrm{M} \mathrm{NaClO}_{4}$ concentrations $(0.15 \mathrm{mM}$ base concentration). 
Table 2. Thermodynamic parameters for A-Z transition of various $\mathrm{m}^{8} \mathrm{Gm}$-containing RNAs.

\begin{tabular}{lccc}
\hline \multicolumn{1}{c}{ Oligonucleotides } & $\boldsymbol{T}_{\mathbf{m}}{ }^{\mathbf{1}}\left({ }^{\circ} \mathbf{C}\right)$ & $\Delta \boldsymbol{T}_{\mathbf{m}}\left({ }^{\circ} \mathbf{C}\right)$ & $\Delta \mathbf{G}_{\mathbf{2 9 8}} \mathbf{~}(\mathbf{k c a l} / \mathbf{m o l})$ \\
\hline $\mathrm{r}(\mathrm{CGCGCG})_{2}$ & 33.5 & - & -1.1 \\
$\mathrm{r}\left(\mathrm{CGC}\left[\mathrm{m}^{8} \mathrm{Gm}\right] \mathrm{CG}\right)_{2}$ & 40.0 & +6.5 & -1.7 \\
$\mathrm{r}\left(\mathrm{C}\left[\mathrm{m}^{8} \mathrm{Gm}\right] \mathrm{C}\left[\mathrm{m}^{8} \mathrm{Gm}\right] \mathrm{CG}\right)_{2}$ & 45.7 & +12.2 & -2.1 \\
$\mathrm{r}(\mathrm{CGCGUGCG}) / \mathrm{r}(\mathrm{CGCACGCG})$ & 37.7 & - & -1.7 \\
$\mathrm{r}(\mathrm{CGCGUGCG}) / \mathrm{r}\left(\mathrm{C}\left[\mathrm{m}^{8} \mathrm{Gm}\right] \mathrm{CAC}\left[\mathrm{m}^{8} \mathrm{Gm}\right] \mathrm{CG}\right)$ & 45.7 & +8.0 & -2.5 \\
$\mathrm{r}\left(\mathrm{C}\left[\mathrm{m}^{8} \mathrm{Gm}\right] \mathrm{CGU}\left[\mathrm{m}^{8}{ }^{8} \mathrm{Gm}\right] \mathrm{CG}\right) / \mathrm{r}\left(\mathrm{C}\left[\mathrm{m}^{8} \mathrm{Gm}\right] \mathrm{CAC}\left[\mathrm{m}^{8} \mathrm{Gm}\right] \mathrm{CG}\right)$ & 52.7 & +15.0 & -3.3 \\
\hline
\end{tabular}

${ }^{1}$ Measurement condition: [RNA] $=0.15 \mathrm{mM}$ base concentration, [sodium phosphate buffer $\left.(\mathrm{pH} 7.0)\right]=5 \mathrm{mM}$, $\left[\mathrm{NaClO}_{4}\right]=7 \mathrm{M}$.

In order to obtain the structural information of Z-RNA, we performed an analysis of the 2D NOESY spectra of $\mathrm{r}\left(\mathrm{CGC}\left[\mathrm{m}^{8} \mathrm{Gm}\right] \mathrm{CG}\right)_{2}$. A complete list of ${ }^{1} \mathrm{H}$ chemical shifts was shown in Table S1. The NOE-restrained refinement provided an unequivocal demonstration that the structure of $\mathrm{r}\left(\mathrm{CGC}\left[\mathrm{m}^{8} \mathrm{Gm}\right] \mathrm{CG}\right)_{2}$ is Z-RNA. We observed the strong cross-peaks in 2D-NOESY spectrum from intranucleotide $\mathrm{H}^{\prime} / \mathrm{H} 8 \mathrm{NOEs}$ of $\mathrm{G}_{2}$ and $\mathrm{G}_{6}$ and a special $\mathrm{NOE}$ between $\mathrm{C1}^{\prime} \mathrm{H}$ and $8 \mathrm{CH}_{3}$ of $^{8} \mathrm{Gm}_{4}$. This indicated the syn conformation of all three guanosine residues (Figure $3 b, c)$.

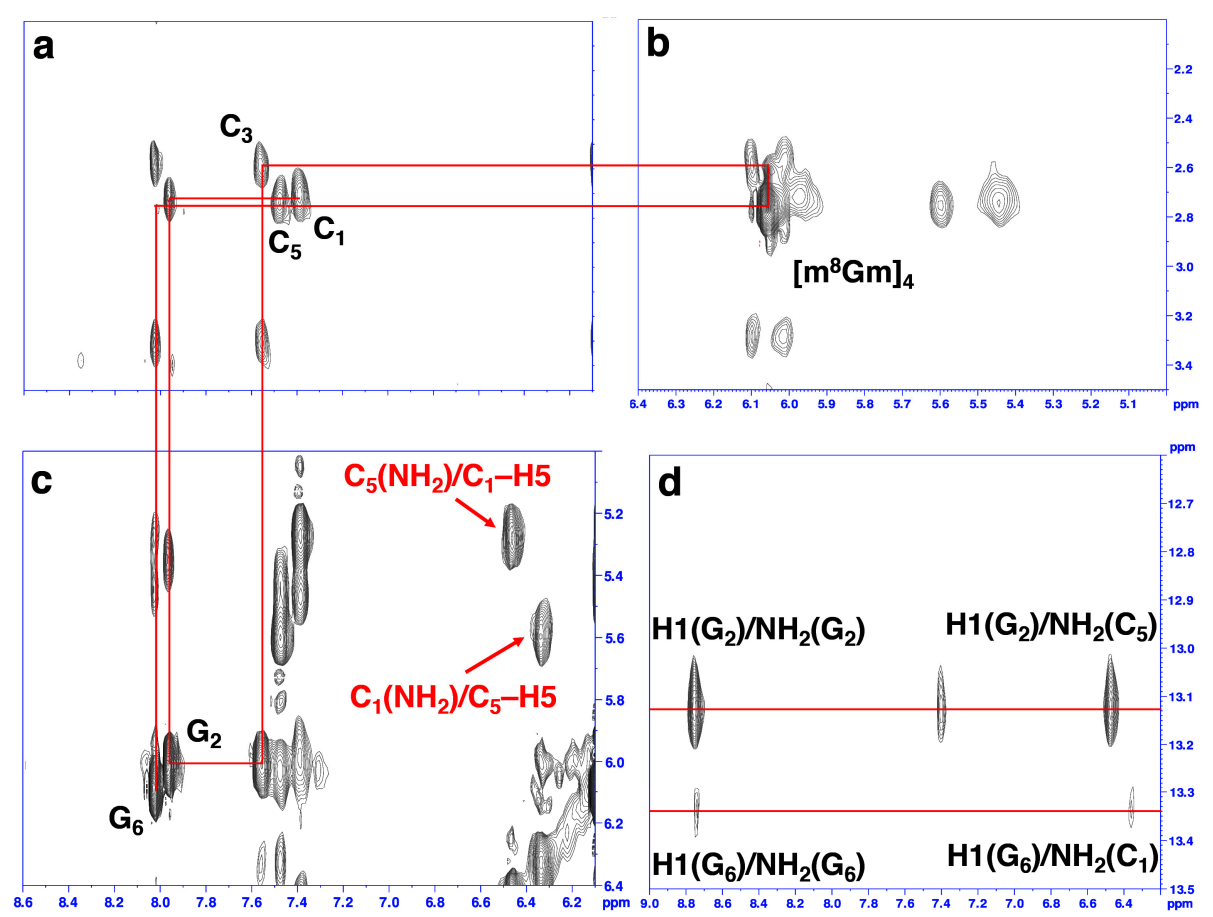

Figure 3. (a-c) $\mathrm{H} 6 / \mathrm{H}^{\prime \prime}$ of $\mathrm{C}$ and $\mathrm{H} 8 / \mathrm{H}^{\prime}$ of $\mathrm{G}\left(8 \mathrm{CH}_{3} / \mathrm{H}^{\prime}\right.$ of $\left.\mathrm{m}^{8} \mathrm{Gm}\right)$ proton region of NOESY spectra of $\mathrm{r}\left(\mathrm{CGC}\left[\mathrm{m}^{8} \mathrm{Gm}\right] \mathrm{CG}\right)_{2}$ in $\mathrm{NaClO}_{4}$ solution. The $\mathrm{NOE}$ connectivity pathway is shown as red line. Intraresidue NOE cross-peaks are labeled with residue numbers. The Z-RNA structure specific cross-peaks were observed between $\mathrm{C}_{5}$ amino protons and $\mathrm{C}_{1} \mathrm{H} 5$ protons from the opposite strand (indicated as red words), as well as between $\mathrm{C}_{1}$ amino protons and $\mathrm{C}_{5} \mathrm{H} 5$ protons from the opposite strand (c). (d) The cross peaks of imino proton of $\mathrm{G}_{2}$ and amino proton of $\mathrm{C}_{5}$, as well as imino proton of $\mathrm{G}_{6}$ and amino proton of $\mathrm{C}_{1}$, indicated Watson-Crick-type base pairs of Z-RNA. Intraresidue NOE cross-peaks of imino and amino proton of $\mathrm{G}_{2}$ and $\mathrm{G}_{6}$ are shown.

The NOE connectivity path between $\mathrm{H} 6 / \mathrm{H}^{\prime \prime}$ of $\mathrm{C}$ and $\mathrm{H} 8 / \mathrm{H} 1^{\prime}$ of $\mathrm{G}\left(8 \mathrm{CH}_{3} / \mathrm{H}^{\prime}\right.$ of $\left.\mathrm{m}^{8} \mathrm{Gm}_{4}\right)$ allows for a cross-peak assignment of Z-RNA nonexchangeable resonances (Figure 3a-c). Sequential assignments of $C_{1}$ to $G_{6}$ for the Z-form can complete the pathway: $C_{1}\left(H 6 / H^{\prime \prime}\right)-G_{2}\left(H 8 / H 1^{\prime}\right)-C_{3}(H 6 /$ $\left.\mathrm{H}^{\prime \prime}\right)-\mathrm{m}^{8} \mathrm{Gm}_{4}\left(8 \mathrm{CH}_{3} / \mathrm{H} 1^{\prime}\right)-\mathrm{C}_{5}\left(\mathrm{H} 6 / \mathrm{H}^{\prime \prime}\right)-\mathrm{G}_{6}\left(\mathrm{H} 8 / \mathrm{H} 1^{\prime}\right)$ (Figure 3a-c), indicating a sequence-specific connectivity for left-handed helices. 
The $\mathrm{H}_{2}{ }_{2}$ resonance was assigned based on NOESY spectra for sequential connections between $\mathrm{H} 6 / \mathrm{H} 8$ and $\mathrm{H}_{2}^{\prime}$ of $\mathrm{C}$ and $\mathrm{G}$ (Figure S11). Moreover, the clear cross-peaks of the imino proton of $\mathrm{G}$ (around $13.0 \mathrm{ppm}$ ) and the amino proton of $C$ suggested WC base pairs (Figure 3d). The 2D NOESY of the imino protons and other protons was used for assignment. For example, we note that the $\mathrm{C}_{5}\left(\mathrm{NH}_{2}\right)$ amino proton has cross-peaks $\left(\mathrm{C}_{5}\left(\mathrm{NH}_{2}\right) / \mathrm{C}_{1}-\mathrm{H} 5\right)$ to the $\mathrm{C}_{1}-\mathrm{H} 5$ proton, and the $\mathrm{C}_{1}\left(\mathrm{NH}_{2}\right)$ amino proton has cross-peaks to the $\mathrm{C}_{5}-\mathrm{H} 5$ proton $\left(\mathrm{C}_{1}\left(\mathrm{NH}_{2}\right) / \mathrm{C}_{5}-\mathrm{H} 5\right)$ (Figure $3 \mathrm{c}$ ). Such cross-peaks can only happen between the two interstrand cytosines between $\mathrm{C} 1$ in one strand and $\mathrm{C} 5$ in another strand of the Z-RNA because of their base pair stacking pattern [28,29].

We further used ${ }^{31} \mathrm{P}-\mathrm{NMR}$ spectroscopy to confirm these observations. We found that these sequences as shown in Table 2 undergo a A-Z transition with increasing $\mathrm{NaClO}_{4}$ from $5 \mathrm{mM}$ to $7 \mathrm{M}$ (Figure 4). These results are consistent with the conformational data from the $\mathrm{CD}$ and proton NMR results.

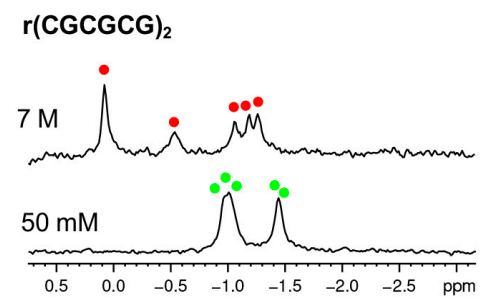

$\mathrm{r}\left(\mathrm{CGC}\left[\mathrm{m}^{8} \mathrm{Gm}\right] \mathrm{CG}\right)_{2}$


$r\left(C\left[m^{8} G m\right] C\left[m^{8} G m\right] C G\right)_{2}$

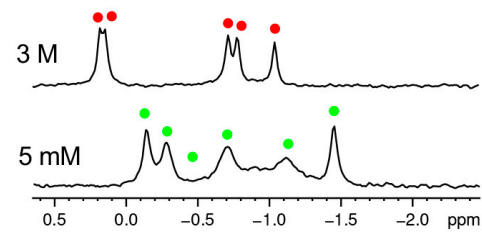

$r\left(C\left[m^{8} \mathrm{Gm}\right] \mathrm{CGU}\left[\mathrm{m}^{8} \mathrm{Gm}\right] \mathrm{CG}\right) /$ $r\left(C\left[m^{8} \mathrm{Gm}\right] \mathrm{CAC}\left[\mathrm{m}^{8} \mathrm{Gm}\right] \mathrm{CG}\right)$
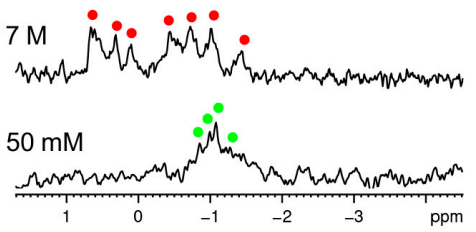

Figure 4. Monitoring of the A to Z-RNA transition by ${ }^{31} \mathrm{P}$ NMR. ${ }^{31} \mathrm{P}$ NMR spectra of the RNAs at $5 \mathrm{mM}-7 \mathrm{M} \mathrm{NaClO}_{4}$. Green and red dots indicate the ${ }^{31} \mathrm{P}$ peaks resulting from A-RNA and Z-RNA, respectively.

A model of $\mathrm{r}\left(\mathrm{CGC}\left[\mathrm{m}^{8} \mathrm{Gm}\right] \mathrm{CG}\right)_{2}$ was constructed based on the reported Z-form structure and NOE-constrained refinement [2]. The molecular dynamics simulations were performed by the standard dynamics cascade in BIOVIA Discovery Studio 4.5 with some modifications. The conformation with the lowest energy was selected as shown in Figure 5. In the $\mathrm{m}^{8} \mathrm{Gm}$-contanied Z-RNA, the C8-methyl groups were hydrophobic and located in the outside of the helix, which is consistent with the induction of a methyl group that strongly contributes to the increased stabilization of Z-RNA.
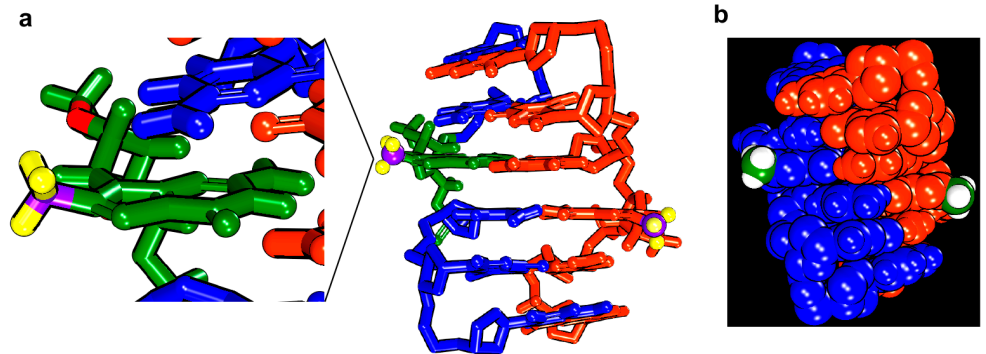

Figure 5. The model for $\mathrm{r}\left(\mathrm{CGC}\left[\mathrm{m}^{8} \mathrm{Gm}\right] \mathrm{CG}\right)_{2}$ Z-RNA structure. (a) $\mathrm{m}^{8} \mathrm{Gm}$ is expanded in green with the C8-methyl group, hydrogen and carbon of methyl group are coloured in yellow and purple. (b) Hydrogen and carbon of methyl group are coloured in green and white. C8-methyl groups were located outside of Z-RNA. 
Encouraged by the ability to use $\mathrm{m}^{8} \mathrm{Gm}$ to stabilize Z-RNA, we study the interaction of the $\mathrm{Z} \alpha$ domain and Z-RNA by using a $\mathrm{m}^{8} \mathrm{Gm}$-containing a Z-RNA and $\mathrm{Z} \alpha$-EGFP fusion protein, in which the $Z \alpha$ domain is tagged with a green fluorescence protein [29]. Figure 6 indicates the visualized mode as EGFP-mode, Cy3-mode and Merge, respectively. Lane 1, lane 2 and lane 3 in Figure 5 show free Z-RNA labeling with fluorescent dye Cy3, a complex of Z-RNA and Z $\alpha$-EGFP and free Z $\alpha$-EGFP, respectively. Green and red fluorescence emission visualized under EGFP-mode and Cy3-mode distinguished $Z \alpha$-EGFP and Z-RNA. Because of the large molecular weight of $Z \alpha$-EGFP, we visualized the complex of the Z $\alpha$-EGFP and Z-RNA in the upper. Lane 2 in merge mode of Figure 6 emitted yellow fluorescence and clearly demonstrated the complex of $Z \alpha$ with Z-RNA. These observations indicated that $Z \alpha$-EGFP efficiently binds to the $\mathrm{m}^{8} \mathrm{Gm}$-containing Z-RNA without severe steric clashes with the added methyl groups, suggesting the $\mathrm{m}^{8} \mathrm{Gm}$ stabilized Z-RNA can be used to investigate the interaction of proteins with Z-RNA.

Recent studies suggested that dsRNA pathways of RNA silencing and micro-RNA regulation were interfered with by ADAR1 [29]. Z $\alpha$ is also reported to enhance ADAR1 editing activity on RNAs with Z-forming sequences in vitro [29]. This suggested that Z-RNA plays important biological roles similar to Z-DNA.
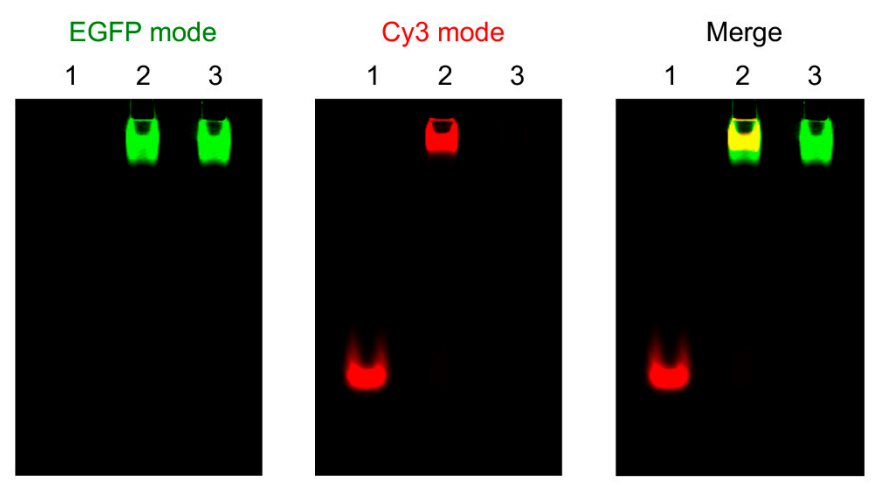

Figure 6. Visualization of Z-RNA and Z $\alpha$-EGFP protein. Lane 1: Z-RNA only, Lane 2: RNA + Z $\alpha$-EGFP, Lane 3: Z $\alpha$-EGFP only. The different modes are indicated in upper. [RNA] $=1 \mu \mathrm{M},[\mathrm{Z} \alpha$-EGFP] $=10 \mu \mathrm{M}$, $[\mathrm{NaCl}]=100 \mathrm{mM},[$ Tris- $\mathrm{HCl}(\mathrm{pH} .0)]=10 \mathrm{mM},[\mathrm{DTT}]=5 \mathrm{mM}, 10 \%$ glycerol, $10 \mu \mathrm{g} / \mathrm{mL}$ BSA. Z-RNA: r(CGCGUGCG)-Cy3/r(C[m $\left.\left.{ }^{8} \mathrm{Gm}\right] \mathrm{CAC}\left[\mathrm{m}^{8} \mathrm{Gm}\right] \mathrm{CG}\right)$.

In conclusion, the results described here reveal that the newly synthesized guanosine analogue 2'-O-methyl-8-methyl guanosine dramatically stabilizes Z-RNA, which arises from the syn conformation of the $\mathrm{m}^{8} \mathrm{Gm}$ base and the $\mathrm{C}^{\prime}$ endo conformation of ribose. The oligonucleotides with AU base pairs can convert into Z-RNA. In addition, researchers can utilize the Z-RNA stabilizer to study the interaction of Z-RNA sequences with the $Z \alpha$ domain. Using the Z-RNA stabilizer, we can refine the structure of Z-RNA based on NMR and examine the molecular basis of Z-form-specific interactions and reactions.

\section{Materials and Methods}

\subsection{Sample Preparation}

We synthesized the RNA oligonucleotides by phosphoramidite chemistry with a DNA/RNA synthesizer. We purified by RP-HPLC and prepared Z $\alpha$-EGFP fusion protein according to the method of Oyoshi et al. [15].

\subsection{Experiments}

We carried out CD experiments by a JASCO J-820 CD spectrophotometer (JASCO Corporation, Tokyo, Japan). The melting curves were obtained by monitoring $285 \mathrm{~nm} .0 .3 \mathrm{~mL}$ samples at $0.15 \mathrm{mM}$ base concentration with $0.1-7 \mathrm{M} \mathrm{NaClO}_{4}, 5 \mathrm{mM}$ sodium phosphate buffer ( $\mathrm{pH} 7.0$ ). 


\subsection{NMR Experiments}

We performed NMR experiments on a Bruker AV-400 M spectrometer (Bruker, Billerica, MA, USA). A special Micro Tube that is designed for use with reduced sample volumes was used (catalog no: NE-H5/3-Br, New Era NMR). Dissolve RNA samples (1.0 mM) in $150 \mu \mathrm{L}$ of $90 \% \mathrm{H}_{2} \mathrm{O} / 10 \% \mathrm{D}_{2} \mathrm{O}, 5 \mathrm{mM}$ sodium phosphate buffer ( $\mathrm{pH} 7.0), 50 \mathrm{mM}$ or $3 \mathrm{M} \mathrm{NaClO}_{4}$. 2D NOE spectra were recorded with mixing times of $500 \mathrm{~ms}$.

\subsection{Molecular Modeling}

The model of RNA structure was manually generated based on the reported structure using the BIOVIA Discovery Studio 4.5 (Accelrys, San Diego, CA, USA). Then molecular dynamics simulations were performed by the standard dynamics cascade in BIOVIA Discovery Studio 4.5 with some modifications. The structure was heating from $50 \mathrm{~K}$ to $300 \mathrm{~K}$ over 4 ps and equilibration at $300 \mathrm{~K}$ with 100 ps simulation time. The save results interval in the production step was 2 ps during 100 ps simulation time at $300 \mathrm{~K} .10$ best conformations generated by simulation were further energy minimized. The conformation with lowest energy was selected as shown in Figure 5.

\subsection{Elctrophoretic Mobility Shift Assay (EMSA)}

We performed the experiments using RNA containing $\mathrm{m}^{8} \mathrm{Gm}$ and Cy3-labeled RNA ( $1 \mu \mathrm{M}$ each) with Z $\alpha$-GFP fusion protein $(10 \mu \mathrm{M})$ in a buffer, $10 \mu \mathrm{g} / \mathrm{mL}$ BSA and $10 \%(v / v)$ glycerol, $100 \mathrm{mM} \mathrm{NaCl}$, $10 \mathrm{mM}$ dithiothreitol, $10 \mathrm{mM}$ Tris- $\mathrm{HCl}$ (pH 7.0). Nondenatured polyacrylamide gel (8\%) is used and performed at $80 \mathrm{~V}$ and $4{ }^{\circ} \mathrm{C}$ in $1 \times$ TBE buffer with $20 \mathrm{mM} \mathrm{NaCl}$.

Supplementary Materials: The following are available online. Schemes S1 and S2: Synthetic scheme of compound 5 and 6, Figures S1-S6: ${ }^{1} \mathrm{H}-\mathrm{NMR}$ spectra of synthesized compounds, Figure S7: HRMS spectra of synthesized compounds, Figure S8: NOESY spectrum of $\mathrm{m}^{8} \mathrm{Gm}$, Figure S9: CD spectra of RNA shown in Table 1 at various $\mathrm{NaClO}_{4}$ concentrations, Figure $\mathrm{S} 10: \mathrm{H} 6 / \mathrm{H}^{\prime}$ of $\mathrm{C}$ and $\mathrm{H} 8 / \mathrm{H}^{\prime}{ }^{\prime}$ of $\mathrm{G}\left(8 \mathrm{CH}_{3} / \mathrm{H} 2^{\prime}\right.$ of $\left.\mathrm{m}^{8} \mathrm{Gm}\right)$ proton region of NOESY spectra of $\mathrm{r}\left(\mathrm{CGC}\left[\mathrm{m}^{8} \mathrm{Gm}\right] \mathrm{CG}\right)_{2}$, Figure S11: Monitoring of the A to Z-RNA transition by ${ }^{31} \mathrm{P}-\mathrm{NMR}$, Table S1: ${ }^{1} \mathrm{H}-\mathrm{NMR}$ chemical shifts $\delta_{\mathrm{H}}$ (p.p.m. of $\mathrm{r}\left(\mathrm{CGC}\left[\mathrm{m}^{8} \mathrm{Gm}\right] \mathrm{CG}\right)_{2}$ Z-RNA.

Author Contributions: Y.X. designed the research. T.B., T.I., C.-D.X., and H.-L.B. carried out the experiments. All authors analyzed the data and wrote the manuscript.

Funding: This work was supported by JSPS KAKENHI Grant Numbers 17H03091 (to Y.X.) and 16K17938 (to T.I.). T.B. is supported by the Otsuka Toshimi Scholarship Foundation. Support from the Takeda Science Foundation is also acknowledged.

Conflicts of Interest: The authors declare no conflict of interest.

\section{References}

1. Popenda, M.; Biala, E.; Milecki, J.; Adamiak, R.W. Solution structure of RNA duplexes containing alternating CG base pairs: NMR study of r(CGCGCG $)_{2}$ and 2'-O-Me(CGCGCG $)_{2}$ under low salt conditions. Nucleic Acids Res. 1997, 25, 4589-4598. [CrossRef] [PubMed]

2. Popenda, M.; Milecki, J.; Adamiak, R.W. High salt solution structure of a left-handed RNA double helix. Nucleic Acids Res. 2004, 32, 4044-4054. [CrossRef] [PubMed]

3. Schwartz, T.; Rould, M.A.; Lowenhaupt, K.; Herbert, A.; Rich, A. Crystal structure of the Zalpha domain of the human editing enzyme ADAR1 bound to left-handed Z-DNA. Science 1999, 284, 1841-1845. [CrossRef] [PubMed]

4. Ha, S.C.; Lowenhaupt, K.; Rich, A.; Kim, Y.G.; Kim, K.K. Crystal structure of a junction between B-DNA and Z-DNA reveals two extruded bases. Nature 2005, 437, 1183-1186. [CrossRef] [PubMed]

5. Kang, Y.M.; Bang, J.; Lee, E.H.; Ahn, H.C.; Seo, Y.J.; Kim, K.K.; Kim, Y.G.; Choi, B.S.; Lee, J.H. NMR spectroscopic elucidation of the $\mathrm{B}-\mathrm{Z}$ transition of a DNA double helix induced by the $\mathrm{Z}$ alpha domain of human ADAR1. J. Am. Chem. Soc. 2009, 131, 11485-11491. [CrossRef] [PubMed]

6. Lee, M.; Kim, S.H.; Hong, S.C. Minute negative superhelicity is sufficient to induce the B-Z transition in the presence of low tension. Proc. Natl. Acad. Sci. USA 2010, 7, 4985-4990. [CrossRef] [PubMed] 
7. Bae, S.; Kim, D.; Kim, K.K.; Kim, Y.G.; Hohng, S. Intrinsic Z-DNA is stabilized by the conformational selection mechanism of Z-DNA-binding proteins. J. Am. Chem. Soc. 2011, 133, 668-671. [CrossRef] [PubMed]

8. Lee, A.R.; Park, C.J.; Cheong, H.K.; Ryu, K.S.; Park, J.W.; Kwon, M.Y.; Lee, J.; Kim, K.K.; Choi, B.S.; Lee, J.H. Solution structure of the Z-DNA binding domain of PKR-like protein kinase from Carassius auratus and quantitative analyses of the intermediate complex during B-Z transition. Nucleic Acids Res. 2016, 44, 2936-2948. [CrossRef] [PubMed]

9. Kim, S.H.; Lim, S.H.; Lee, A.R.; Kwon, D.H.; Song, H.K.; Lee, J.H.; Cho, M.; Johner, A.; Lee, N.K.; Hong, S.C. Unveiling the pathway to Z-DNA in the protein-induced B-Z transition. Nucleic Acids Res. 2018, 46, 4129-4137. [CrossRef] [PubMed]

10. Schwartz, T.; Behlke, J.; Lowenhaupt, K.; Heinemann, U.; Rich, A. Structure of the DLM-1-Z-DNA complex reveals a conserved family of Z-DNA-binding proteins. Nat. Struct. Biol. 2001, 8, 761-765. [CrossRef] [PubMed]

11. Rothenburg, S.; Deigendesch, N.; Dittmar, K.; Koch-Nolte, F.; Haag, F.; Lowenhaupt, K.; Rich, A. A PKR-like eukaryotic initiation factor $2 \alpha$ kinase from zebrafish contains Z-DNA binding domains instead of dsRNA binding domains. Proc. Natl. Acad. Sci. USA 2005, 2, 1602-1607. [CrossRef] [PubMed]

12. Kahmann, J.D.; Wecking, D.A.; Putter, V.; Lowenhaupt, K.; Kim, Y.G.; Schmieder, P.; Oschkinat, H.; Rich, A.; Schade, $\mathrm{M}$. The solution structure of the $\mathrm{N}$-terminal domain of E3L shows a tyrosine conformation that may explain its reduced affinity to Z-DNA in vitro. Proc. Natl. Acad. Sci. USA 2004, 101, 2712-2717. [CrossRef] [PubMed]

13. Sugiyama, H.; Kawai, K.; Matsunaga, A.; Fujimoto, K.; Saito, I.; Robinson, H.; Wang, A.H. Synthesis, structure and thermodynamic properties of 8-methylguanine-containing oligonucleotides: Z-DNA under physiological salt conditions. Nucleic Acids Res. 1996, 24, 1272-1278. [CrossRef] [PubMed]

14. Kawai, K.; Saito, I.; Sugiyama, H. Conformation-Dependent Photochemistry of 5-Halouracil-Containing DNA: Stereospecific 2' $\alpha$-Hydroxylation of Deoxyribose in Z-form DNA. J. Am. Chem. Soc. 1999, 121, 1391-1392. [CrossRef]

15. Oyoshi, T.; Kawai, K.; Sugiyama, H. Efficient C2'alpha-hydroxylation of deoxyribose in protein-induced Z-form DNA. J. Am. Chem. Soc. 2003, 125, 1526-1531. [CrossRef] [PubMed]

16. Tashiro, R.; Sugiyama, H. A nanothermometer based on the different pi stackings of B- and Z-DNA. Angew. Chem. Int. Ed. 2003, 42, 6018-6020. [CrossRef] [PubMed]

17. Xu, Y.; Ikeda, R.; Sugiyama, H. 8-Methylguanosine: A powerful Z-DNA stabilizer. J. Am. Chem. Soc. 2003, 125, 13519-13524. [CrossRef] [PubMed]

18. Xu, Y.; Zhang, Y.X.; Sugiyama, H.; Umano, T.; Osuga, H.; Tanaka, K. (P)-helicene displays chiral selection in binding to Z-DNA. J. Am. Chem. Soc. 2004, 126, 6566-6567. [CrossRef] [PubMed]

19. Chen, F.Y.; Park, S.; Otomo, H.; Sakashita, S.; Sugiyama, H. Investigation of B-Z transitions with DNA oligonucleotides containing 8-methylguanine. Artif. DNA PNA XNA 2014, 5, e28226. [CrossRef] [PubMed]

20. Park, S.; Otomo, H.; Zheng, L.; Sugiyama, H. Highly emissive deoxyguanosine analogue capable of direct visualization of B-Z transition. Chem. Commun. 2014, 50, 1573-1575. [CrossRef] [PubMed]

21. Vongsutilers, V.; Gannett, P.M. C8-Guanine modifications: Effect on Z-DNA formation and its role in cancer. Org. Biomol. Chem. 2018, 16, 2198-2209. [CrossRef] [PubMed]

22. Bothe, J.R.; Lowenhaupt, K.; Al-Hashimi, H.M. Sequence-specific B-DNA flexibility modulates Z-DNA formation. J. Am. Chem. Soc. 2011, 133, 2016-2018. [CrossRef] [PubMed]

23. Brown, B.A.; Lowenhaupt, K.; Wilbert, C.M.; Hanlon, E.B.; Rich, A. The Z $\alpha$ domain of the editing enzyme dsRNA adenosine deaminase binds left-handed Z-RNA as well as Z-DNA. Proc. Natl. Acad. Sci. USA 2000, 97, 13532-13536. [CrossRef] [PubMed]

24. Kypr, J.; Kejnovska, I.; Renciuk, D.; Vorlickova, M. Circular dichroism and conformational polymorphism of DNA. Nucleic Acids Res. 2009, 37, 1713-1725. [CrossRef] [PubMed]

25. Yamamoto, S.; Park, S.; Sugiyama, H. Development of a visible nanothermometer with a highly emissive 2'-O-methylated guanosine analogue. RSC Adv. 2015, 5, 104601-104605. [CrossRef]

26. Cummins, L.L.; Owens, S.R.; Risen, L.M.; Lesnik, E.A.; Freier, S.M.; McGee, D.; Guinosso, C.J.; Cook, P.D. Characterization of fully 2'-modified oligoribonucleotide hetero- and homoduplex hybridization and nuclease sensitivity. Nucleic Acids Res. 1995, 23, 2019-2024. [CrossRef] [PubMed] 
27. Uesugi, S.; Ohkubo, M.; Urata, H.; Ikehara, M.; Kobayashi, Y.; Kyogoku, Y. Ribooligonucleotides, r(C-G-C-G) analogs containing 8-substituted guanosine residues, form left-handed duplexes with Z-form-like structure. J. Am. Chem. Soc. 1984, 6, 3675-3676. [CrossRef]

28. Chen, G.; Znosko, B.M.; Kennedy, S.D.; Krugh, T.R.; Turner, D.H. Solution structure of an RNA internal loop with three consecutive sheared GA pairs. Biochemistry 2005, 44, 2845-2856. [CrossRef] [PubMed]

29. Placido, D.; Brown, B.A., 2nd; Lowenhaupt, K.; Rich, A.; Athanasiadis, A. A left-handed RNA double helix bound by the $\mathrm{Z} \alpha$ domain of the RNA-editing enzyme ADAR1. Structure 2007, 15, 395-404. [CrossRef] [PubMed]

Sample Availability: Samples of the compounds are not available from the authors.

(C) 2018 by the authors. Licensee MDPI, Basel, Switzerland. This article is an open access article distributed under the terms and conditions of the Creative Commons Attribution (CC BY) license (http:// creativecommons.org/licenses/by/4.0/). 